\title{
熱間工具鋼の実用特性に及ぼす焼入れ冷却速度 の影響
}

\author{
上原 紀 興*, 並木 邦夫**, 高橋 国 男***
}

\section{Effect of Quenching Cooling Rate on thẹ Practical Properties of Hot-Work Tool Steel}

\section{Norioki Uehara, Kunio Namiki and Kunio Takahashi}

\begin{abstract}
Synopsis
Effect of cooling rate on commercially significant properties of hot-work tool steel has been studied using JIS SKD 61 .

When cooled through bainite or pearlite and bainite region and tempered to the practical hardness level, $\mathrm{HRC} 45$, resistance to softening, toughness, and heat checking resistance deteriorate. It is revealed that coarsening and segregation of carbides by tempering, which have been already precipitated during bainite or pearlite transformation, result in deterioration of mechanical properties.

Further, directionality and uniformity of mechanical properties for large sectioned forging have been also investigated. The ratio of transverse to longitudinal toughness and ductility values are proved to be $0.75-0.85$.
\end{abstract}

\section{1. 緒}

近年の自動車，家電製品などの大量生産の発達 にともなって，これらの部品を製造するための金 型に対するニーズもより苛酷なるのとなってい る。特に熱間鍛造金型やダイカスト金型等の熱間 成形用金型は，生産量の増大，成形の高速化にと むなら強冷却の実施や，大型金型の適用に対処す るため, 新鋼種の開発のみならず金型の製造方法, 熱処理方法をも含めた総合的な検討が必要となっ ている。一般に熱間成形用金型は大型のものが多 いにもかかわらす，熱間工具鋼の暁入性に関する

\footnotetext{
昭和56年 6 月 12 日 受付

*大同特殊鋼侏知多工場, 工博

**大同特殊鋼秼研究開発本部中央研究所

***大同特殊鋼秼技術サービス部
}

研究は少なく”，硬さだけでなく勒延性，軟化抵抗 をも含めた多面的な質量効果の研究は最近になっ てよ5やく開始されるに至っだ)3)。

一方，金型の寿命を支配する特性は表面の耐摩 耗性，耐肌荒れ性に関与寸る軟化抵抗と，耐割れ 性に関与するヒートチェック性および勒延性に大 別できる。

そこで, 本研究では熱間工具鋼, SKD 61 の大型 素材を用い、これらの特性に及ぼす焼入れ冷却速 度の影揞を求め，金型寿命向上のための基礎資料 とすることにした。

\section{2. 実 験 方 法}

\section{1 供 試 材}

熱間成形用金型として一般的に用いられている 熱間工具鋼 SKD 61 を用いた。 $6 \mathrm{t}$ 鋼塊より1/2に 
Table 1. Chemical composition of the test steel. $(w t \%)$

\begin{tabular}{c|c|c|c|c|c|c|c|c|c}
\hline $\mathrm{C}$ & $\mathrm{Si}$ & $\mathrm{Mn}$ & $\mathrm{P}$ & $\mathrm{S}$ & $\mathrm{Ni}$ & $\mathrm{Cu}$ & $\mathrm{Cr}$ & $\mathrm{Mo}$ & $\mathrm{V}$ \\
\hline 0.38 & 0.97 & 0.37 & 0.026 & 0.020 & 0.14 & 0.07 & 5.12 & 1.19 & 0.86 \\
\hline
\end{tabular}

据え込み後，11.7Sの鍛錬比をかけて製造した $\phi 350$ の素材を用い，その外周部（外周から $25 \mathrm{~mm}$ 以内）と中心部（中心を含を $\phi 50 ）$ から試験片を 採取した。供試材の化学成分をTable 1 に示す。

\section{2 等 処 理}

各試験片は $1030^{\circ} \mathrm{C}$ で $30 \mathrm{~min}$ 保持してオーステ ナイト化処理を行った後， 3 通りの泠却速度で冷 却した。SKD 61 のCCT 曲線と試験片の冷却曲線 をFig. 1 に示す。冷却速度 I はマルテンサイト組 織としたもの，IIはへイイナイト変態開始点付近を 通過させたもの，IIIはパーライト変態域の先端に 毷け，さらに高温でべイナイト変態域を通過させ たすのである。それぞれの 500〜300ㄷ における 平均冷却速度は $4.8,0.11,0.03^{\circ} \mathrm{C} / \mathrm{sec}$ である。焼 むどしは各温度で $1 \mathrm{hr}$ 保持後空冷とし，これを 2 回繰返した。

\section{3 試 験 方 法}

焼もとしし硬さ，軟化抵抗の測定には $15 \mathrm{~mm} \times 15$ $\mathrm{mm} \times 10 \mathrm{~mm}$ の試験片を用いた。

シャルビー試験はJIS 3 号試験片，引張試験は

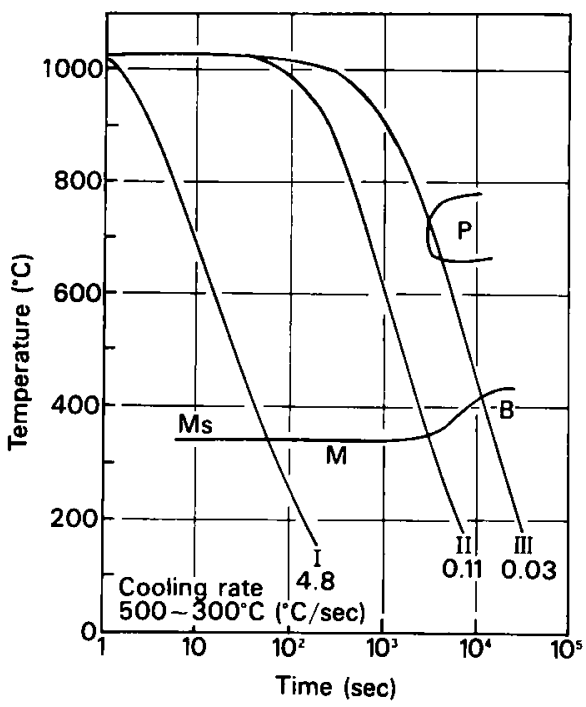

Fig. 1. CCT diagram for the steel investigated.
平行部, $\phi 6 \times 26 \mathrm{~mm} l$ の試験片を用いて試験を行 った。

ヒートチェック試験はフレーム加熱方式にて行 い，最高温度 $600^{\circ} \mathrm{C}$ および $700^{\circ} \mathrm{C}$ と水温 (15〜 $\left.20^{\circ} \mathrm{C}\right) を 1000$ 回繰返した。ヒートチェック試験機 を Fig. 2 に示す。試験後，フレームの中心が検鏡 面になるよ5切断, 研磨の後, クラック深さ，ク ラック数を求めて耐ヒートチェック性を評価し た。

炭化物の同定はX楾法によって行った。0.2N， $\mathrm{HCl}+5 \%$ クエン酸の電解液を用い, $25 \mathrm{~mA}$ の電 流密度で定電流電解分離を行って炭化物残渣を抽 出し，X線回折によって各炭化物からの相対 X線 強度を求めた。

残留オーステナイト量は，X線回折法を用い， $\alpha$ 相 (211) 面，および $\gamma$ 相（220）面からのX線 回折強度を求めて算出した。

\section{3. 実験結果および考察}

\section{1 焼もとし硬さ，軟化抵抗に及ぼす烧入れ 冷却速度の影量}

$\phi 350$ 材の外周部から採取した試験片を用いて 求めた焼もどし硬さと狫もとし温度の関係を Fig. 3 に示す。焼入れ硬さは冷却速度の小さいほ ど低下し，さらに 2 次硬化の過程において冷却速 度の影䉒が顕著に認められる。冷却速度IIでは2

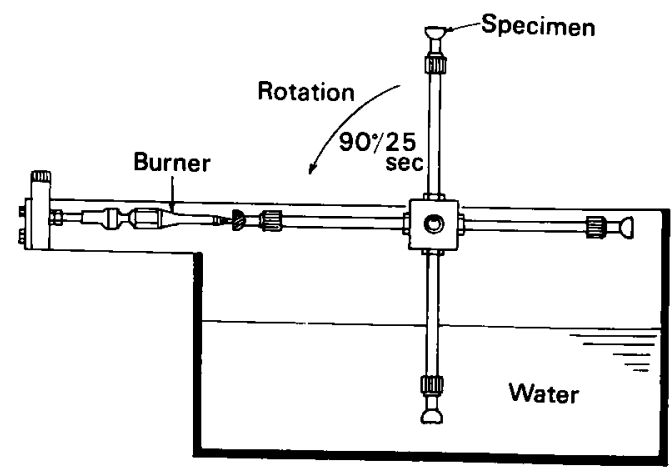

Fig. 2. Heat check testing apparatus. 


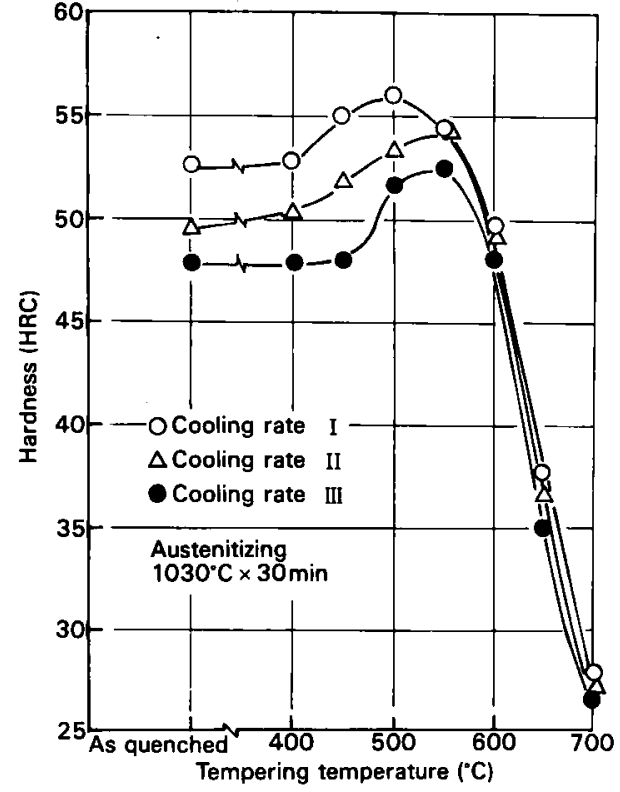

Fig. 3. Effect of quenching cooling rate on tempering hardness.

次硬化のピークが高温側に移動するが,これより 高温では冷却速度 I と同じ硬さになる。これに対 し冷却速度III では 2 次硬化を示すものの最高硬さ はI，IIに比べて低く，また高温側でも若千低い 値を示す。

さらに焼もどしによって HRC45士 1 に調質 後, $600^{\circ} \mathrm{C}$ で長時間保持した時の硬さと保持時間 の関係を Fig. 4 に示す。冷却速度 I と II ではほほ 同じ硬さ推移曲線を示すが，冷却速度IIIでは硬さ の低下が著しいことが判明した。

\section{2 ミクロ組織, 残留オーステナイト量, 炭 化物反応}

焼もどし硬さ，軟化抵抗に認められた焼入れ冷 却速度の影響を考察するため，ミク口組織観察お よび残留オーステナイト量の測定を行った。各冷 却速度で冷却した時の焼入れ組䄳，および $620^{\circ} \mathrm{C}$ で焼もとしを施した時の光学䫓锺鏡組織をPhoto. 1 に示す。冷却速度 IIで焼入れした場合，下部 ペイナイトと考えられる針状組織が観察され，冷 却速度 III ではパーライトがわずかに出現し，さら に塊状のペイナイトが観察される。これに焼もど しを施すとぺイナイトおよびパーライトとペイナ イトに睁けて冷却したII，IIIでは旧オーステナイ ト粒界が顕著に現出し，さらに粒内にも炭化物が

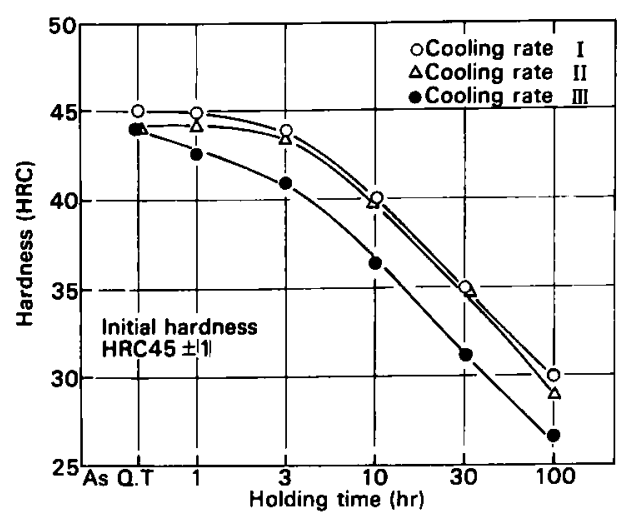

Fig. 4. Relation between hardness and holding time at $600^{\circ} \mathrm{C}$.

凝集している様子がうかがえる。

次に残留オーステナイト量と焼もどし温度の関 係を Fig. 5 に示す。焼入れ状態では冷却速度の小 さいはど残留オーステナイト量が增加し，冷却速 度IIIでは約 $20 \% に$ 達する。またこれらの残留オー

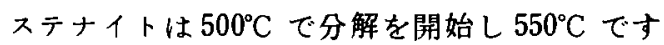
べて分解する。従って，500〜 $550^{\circ} \mathrm{C}$ で認められる 本鋼種の 2 次硬化は炭化物の析出による硬さ上昇 とともに残留オーステナイトの分解による寄与が 大きいと考えられる。

さらに焼もどしにともなら炭化物反応を調べた 結果を Fig. 6 に示す。冷却速度 I では未溶解炭化 物としてV が認められ， $500^{\circ} \mathrm{C}$ から $\mathrm{M}_{7} \mathrm{C}_{3}$, $650^{\circ} \mathrm{C}$ からは $\mathrm{M}_{6} \mathrm{C}$ 型炭化物の析出が認められる。 これに対し冷却速度IIIの場合, 焼入れ状態でV C の他に， $\mathrm{M}_{7} \mathrm{C}_{3}$ および $\mathrm{M}_{23} \mathrm{C}_{6}$ 型の炭化物が認めら れた。これらの炭化物はッ゙ーライト変態およびへ イナイト変態時に析出したものと考えられ，650 $\sim 700^{\circ} \mathrm{C}$ の焼もどしを施すと，特に $\mathrm{M}_{23} \mathrm{C}_{6}$ 型炭化 物の相対強度が増大することが確認された。

従って，冷却速度IIIで㛙入れを行った場合，I と同等の焼むとし硬さを示さず，さらに軟化抵抗 も贫化する理由は以下のよらに考えられる。すな わち，冷却速度IIIでは残留オーステナイトの分解 によって2 次硬化を示すものの，焼入れ冷却過程 で炭化物が既に析出しているため炭化物形成元素 が析出硬化に十分奇与しないこと，さらに焼入れ 時に析出した炭化物は高温での焼もどしによって 容易に凝集，粗大化するためであろ5。3 通りの 冷却速度で焼入れ後, $620^{\circ} \mathrm{C} て ゙$ 焼もどしを行った 


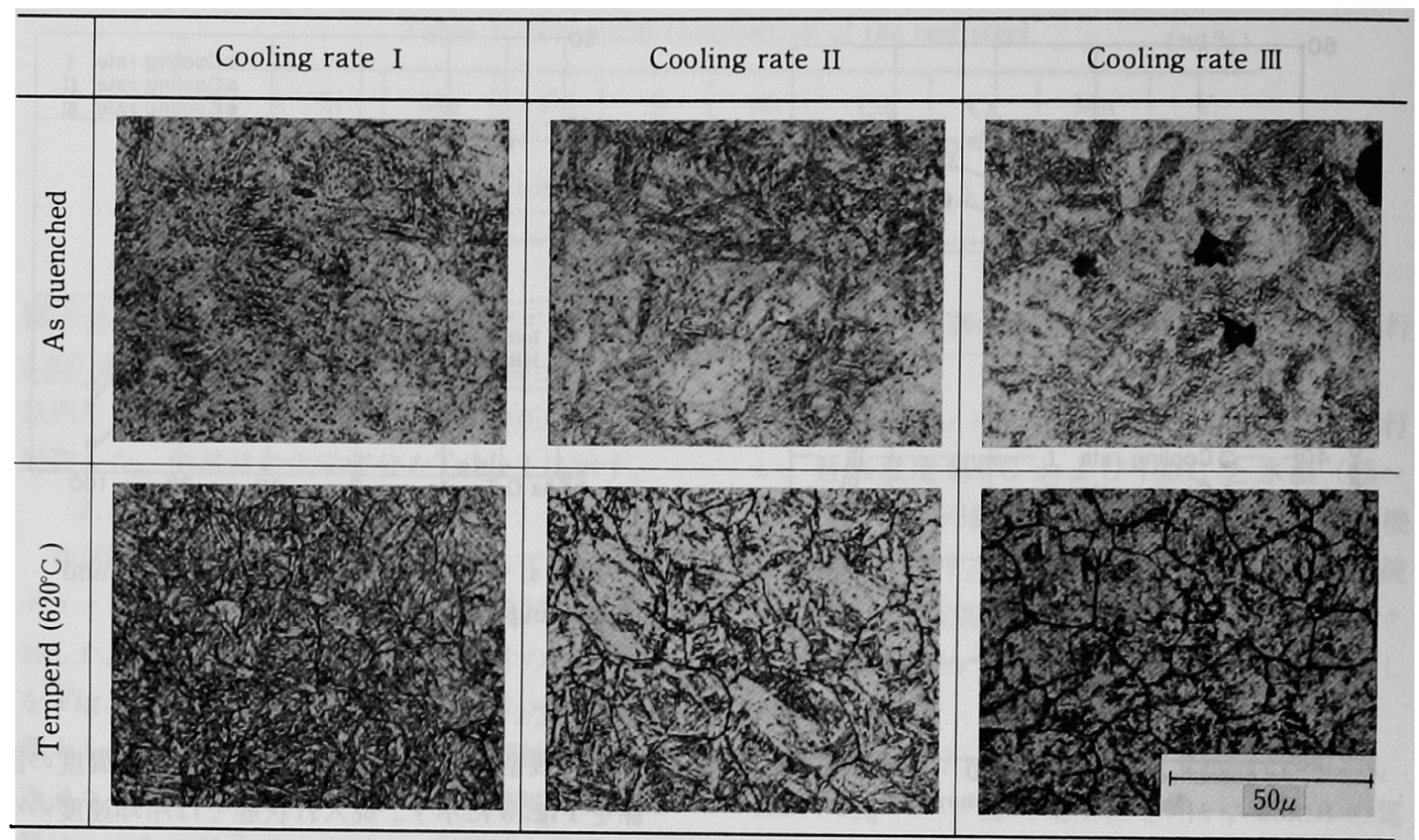

Photo. 1. Effect of cooling rate on the optical microstructures of the test steel.

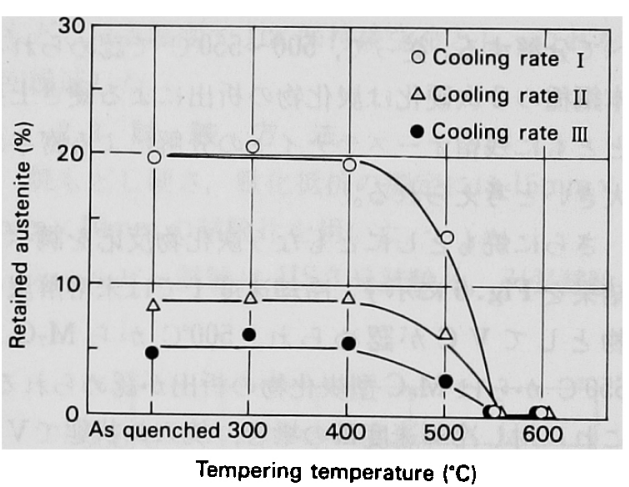

Fig. 5. Effect of tempering temperature on amount of retained austenite.

時の電子䫒溦鏡組織をPhoto. 2 に示す。冷却速度 I では炭化物が微細，均一に分散しているのに対 し, 冷却速度の減少にともなって，炭化物の凝集， および粗大化が著しいことが判明した。

\section{3 機械的性質}

外周部の試験片を用い，I～III の冷却速度で冷 却した後，焼もどしによって HRC40〜50の間に 調質した時のシャルピー衝撃値を Fig. 7 に示す。 HRC48 以上の硬さでは冷却速度の差は認められ ないがこれより硬さが低い場合には冷却速度 II およびIIIはI の $2 / 3 〜 1 / 2$ まで低下する。同様にして

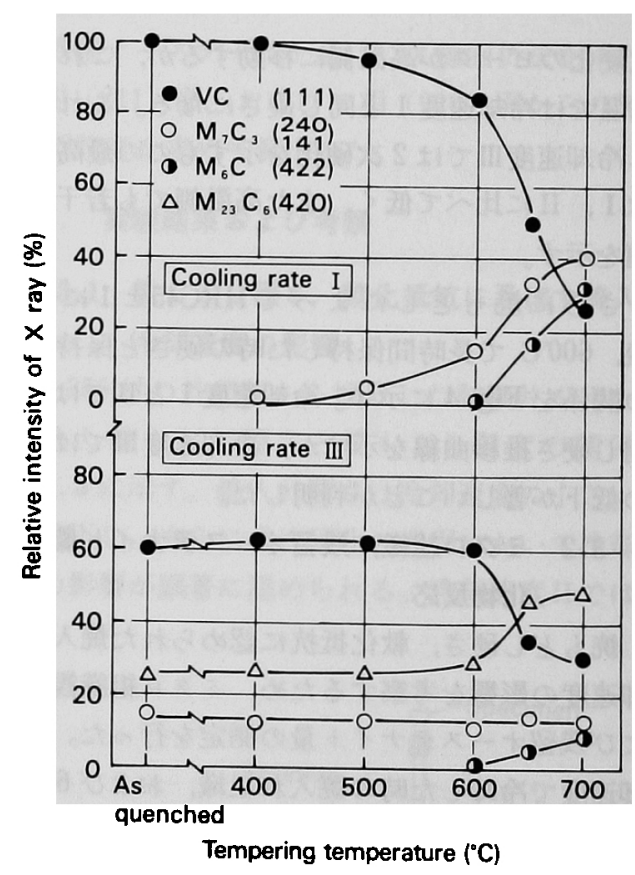

Fig. 6. Relative intensities of $\mathrm{X}$ ray diffraction of carbides.

中心部から採取した試験片によっても硬さと衝軗 値の関係を求め，HRC45に护ける值を用いて外 周と中心部の衝撃値を冷却速度で整理した結果を Fig. 8 に示す。冷却速度に比へ, 試験片採取位置の 


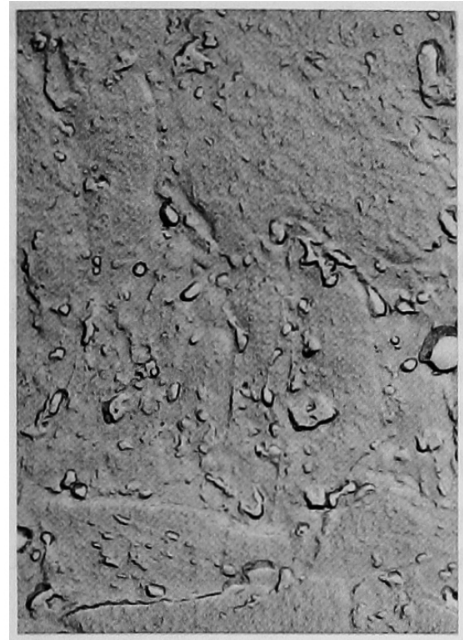

Cooling rate $I$

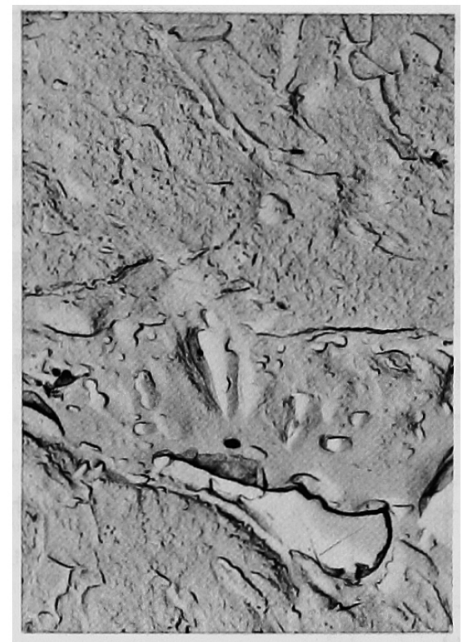

Cooling rate II

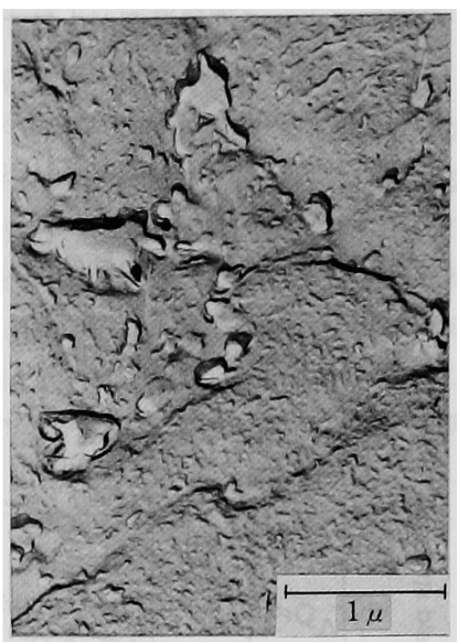

Cooling rate III

Photo. 2. Effect of quenching cooling rate on the electron microstructures of specimens tempered at $620^{\circ} \mathrm{C}$.

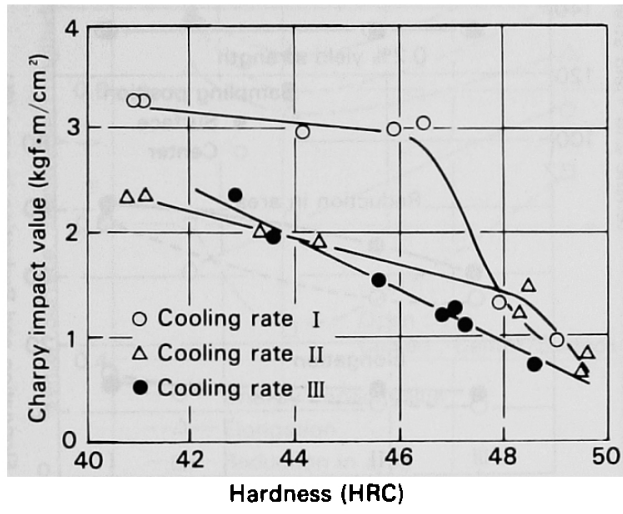

Fig. 7. Effect of quenching cooling rate on Charpy impact values.

(Sampling position : Surface, Longitudinal)

盖はほとんと認められなかった。次に同様の方法 によって求めた引張特性と硬さの関係，および引 張特性に及ほ卞冷却速度と試験片採取位置の関係 をFig. 9，10 に示す。伸び，絞り値においても冷 却速度の影響が明瞭に認められ，採取位置につい ては特に絞り值において外周部と中心部の差が顕 著であった。

従来より高張力鋼や機械構造用鋼については, 蛄入れ組織之勒延性の関係について多くの研究が 行われており ${ }^{5114) ， マ ル テ ン サ イ ト お よ ひ ゙ へ イ ナ ~}$ イト,残留オーステナイトとの混合組織について, その功罪が检討されている ${ }^{15)-20)}$ 。しかし熱間工具

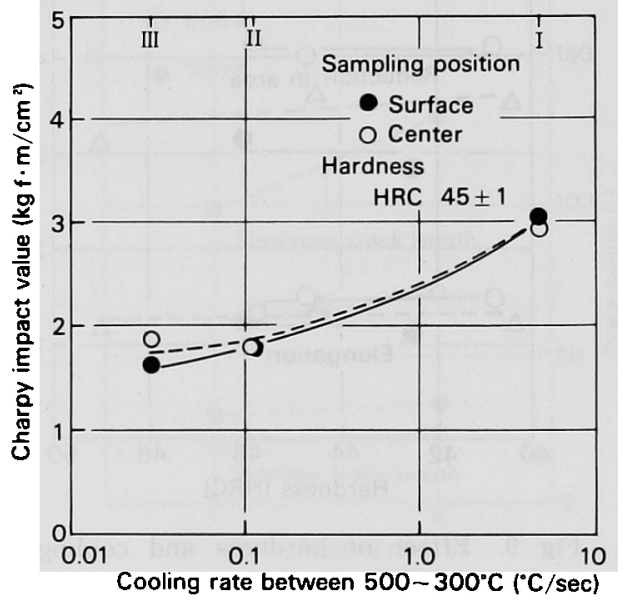

Fig. 8. Effect of quenching cooling rate and sampling position on Charpy impact value.

鋼の場合にこれらに比べ $\mathrm{Ms}$ 点が低いこと、さらに 複雑な炭化物反応を伴らなどの理由により詳細な 検討はほとんど行われていない。本実験において 焼入れ冷却速度の小さいほど 2 次硬化域を越えて 蝰むどしを施した場合に勒延性や劣化する理由は 以下のよらに考えられる。まず, ペイナイトおよ びハーーライトとベイナイトに懸けて冷却した場 合，焼もとし時に炭化物の粗大化，凝集が起りゃ すいため，これらか脆性破壊の起点になることが 挙げられる。中島 ${ }^{21} ら は$ 炭化物の大きさ，面積率 
の增加によって遷移温度が上昇することを報告し て打り，炭化物は応力集中をもたらしクラックの 発生を容易に寸ると考えて良からら。さらに狫も どしマルテンサイトと焼もどしべイナイトではク ラックの伝播抵抗が異なり，焼もどしベイナイト の場合，脆性破壈の破面単位が大きくなるため靶

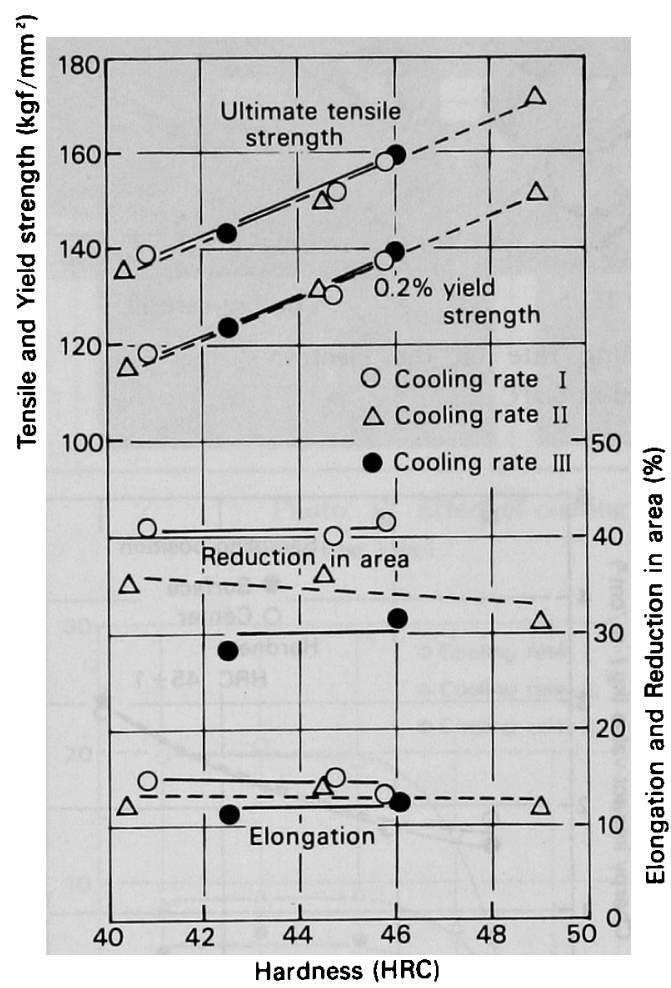

Fig. 9. Effect of hardness and cooling rate on tensile properties.

(Sampling position : Surface, Longitudinal)
延性が劣化するものと考えられる。シャルビー衝 擊破面の例をPhoto. 3 に示す。冷却速度 I ではデ ィンブルと擬䢃開の混合する破面を呈するが，冷 却速度II，IIIではディンブルが認められず，さら に擬䢃開の破面単位も大きいことが判明した。

次に大型素材における機械的性質の試験片採取 仕置および採取方向の差について検討する。引張 強度, $0.2 \%$ 耐力には差が認められず,ンャルビー 衝撃値, 伸び, 鉸りにこれらの影響が認められた。 鍛伸方向（L方向）における中心部／外周部の比, 外周部における円周方向 $(\mathrm{T})$ /鍛伸方向 $(\mathrm{L})$ の比を焼入れ冷却速度で整理した結果を Fig. 11

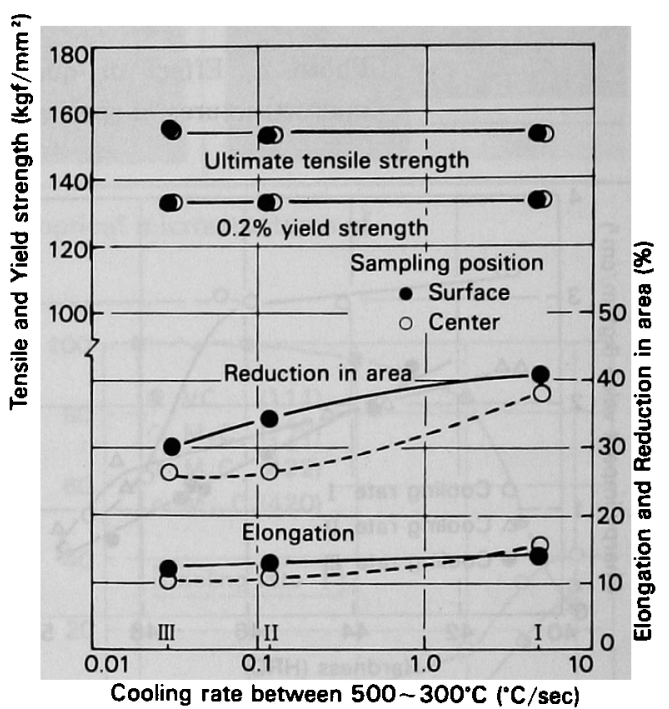

Fig. 10. Effect of quenching cooling rate and sampling position on tensile properties.

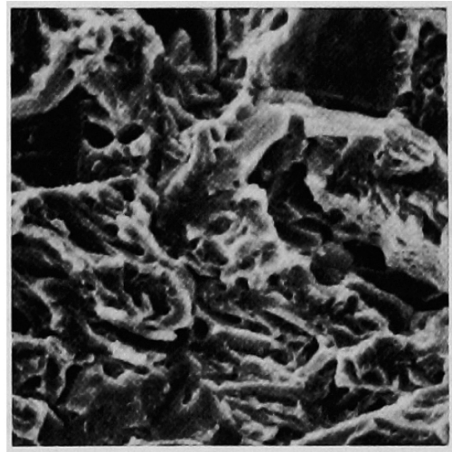

Cooling rate $\mathrm{I}$

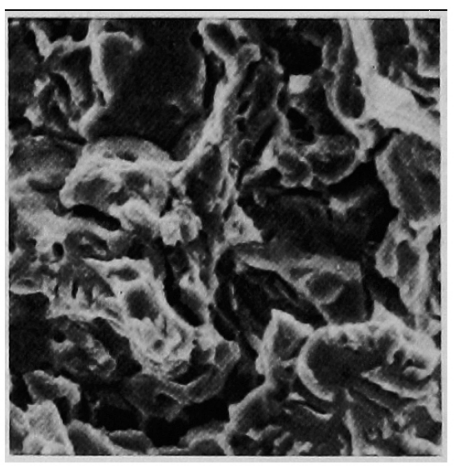

Cooling rate II

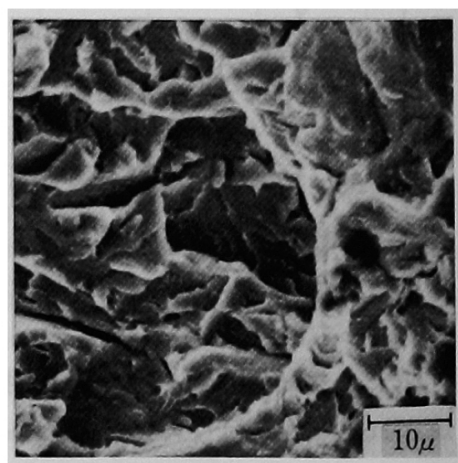

Cooling rate III

Photo. 3. Scanning electron micrographs of fracture surfaces of Charpy impact specimens quenched and tempered at $620^{\circ} \mathrm{C}$. 
に示す。その結果，内外周の差に比べ方向性が顕 著に認められ，冷却速度 Iでは，中心部/外周部 の比が0.95〜1.0であるのに対 L, T方向／L方向 の比は0.70〜0.85であることが判明した。 Rardaku ${ }^{22)}$ らは $\phi 340$ の $0.4 \mathrm{C}-5 \mathrm{Cr}-1.4 \mathrm{Mo}-1 \mathrm{~V}$ 鋼 を用い，機械的性質の均質性，方向性と鐉鍊比の 関係を求めている。その結果，鍜錬比か４ を越え ると靶延性値はほほ飽和し，鉎鍊比 8 における中 心部/外周部，およびT方向／L方向の比をそれ ぞれ0.9〜1.0，0.6〜0.75と報告しており，本実験 結果もこれらの值とおおむね挃した。さらに焼 入れ冷却速度の小さい汪と均質性, 方向性とも劣 化する傾向が認められた。

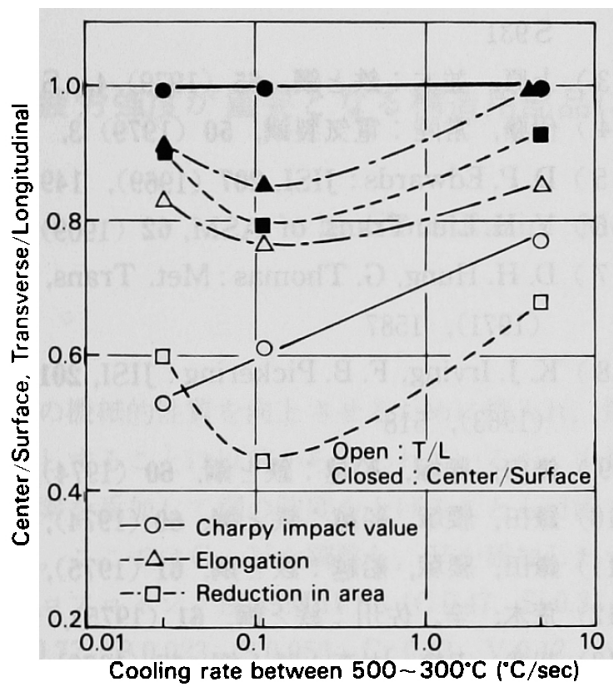

Fig. 11. Effect of cooling rate on directionality and uniformity of mechanical properties.

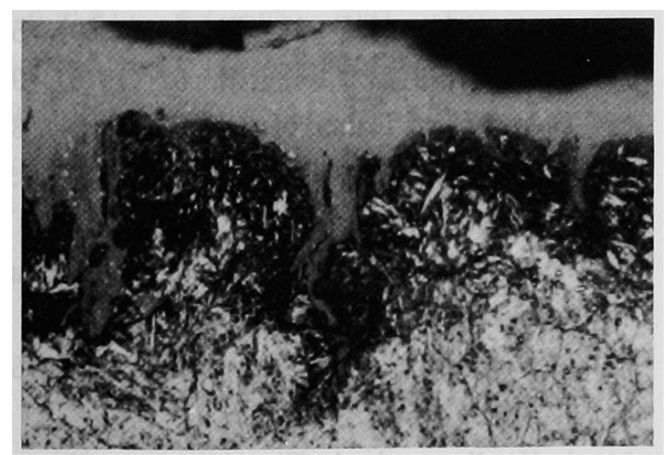

Cooling rate $\mathrm{I}$
3.4 耐ヒートチェック性

外周部から採取した試験片を用い，HRC45士 1 に調質した後, 最高加熱温度を $600^{\circ} \mathrm{C} と 700^{\circ} \mathrm{C} の 2$ 通りに選んでヒートチェック試験を行った結果を Fig. 12 に示す。加熱温度の上昇にともなってクラ ック数は減少し，最大クラック深さおよび平均 クラック深さは深くなる。冷却速度の影譬を見る と冷却速度IIIはIに比べクラック深さが深くな ク，特に最大クラック深さが深くなることが判明 しだ。一般に金型のクラックは製品に転写したり，

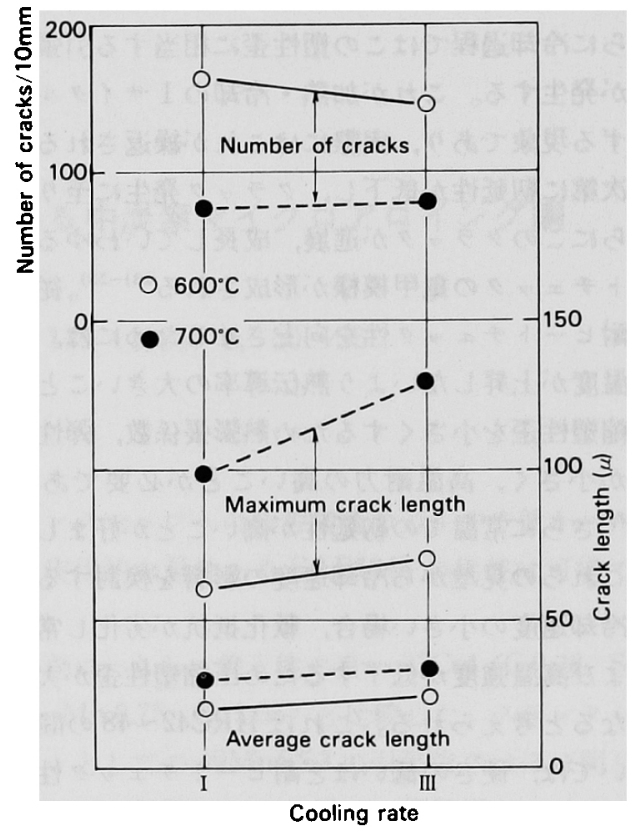

Fig. 12. Effect of quenching cooling rate on heat-check properties.

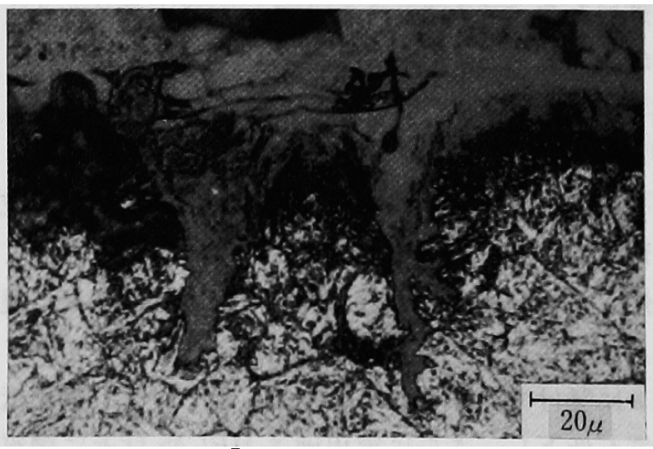

Cooling rate III

Photo. 4. Cross sectional views of heat checks $\left(20^{\circ} \mathrm{C} \underset{\text { cycles }}{\stackrel{1000}{\longrightarrow}} 600^{\circ} \mathrm{C}\right)$. 
大割れの起点になることを考えれば，最大クラッ ク深さをるって耐ヒートチェック性を評洒するの が妥当であり，従って冷却速度の減少にともなっ て耐ヒ一トチェック性は劣化すると判断して良か ろら。ヒートチェック試験片の断面観察結果を Photo. 4 に示寸。

次にこれらの実験結果を考察するため，まずヒ ートチェックの発生機構から考えてみたい。金型 表面が高温にさらされる場合, 局部的な膨張が心 部によって拘束されるため正縮応力が生ずる。表 面温度の上昇にともなって王縮応力は增加し，降 伏点を越えると压縮塑性歪が生するであらら。さ らに冷却過程ではこの塑性垔に相当する引張応力 が発生する。これが加熱・冷却の1サイクルに生 ずる現象であり，実際にはこれが繰返されるため 次第に勒延性が低下し，クラック発生に至り，さ らにこのクラックが進展, 成長していわゆるヒー トチェックの刍甲模様が形成される231 251。従って 耐ヒートチェック性を向上させるためには，表面 温度か上昇しないよら熱云導率の大きいこと，圧 樎塑性昰を小さくするため熱膨張係数, 弾性係数 が小さく，高温耐力の高いことが必要であり 28)さらに常温での靯延性が高いことが好ましい。 これらの見地から冾却速度の影響を検討すると， 冷却速度の小さい場合, 軟化抵抗が劣化し常温お よび高温強度が低下するため縮塑性歪が大きく なると考えられる。これは HRC42〜48 の間にお いては，硬さの低いほど耐ヒートチェック性が劣 化する ${ }^{2930)}$ ことからも襄付けられるであらう。さ らに冷却速度の減少にもとなってンャルビー衝撃 值，伸び，絞りが低下するため，等しい熱衝撃す なわち加熱・冷却サイクルを受けてもクラックが 進展しやすくなり，ヒートチェックが深くなると 考えられる。

\section{4. 榙}

熱間工具鋼，SKD 61 の大型素材を用い，熱間成 形甲金型として必要とされる種々の特性についてて 焼入れ冷却速度の影響を検討した。その結果，焼 入れ時にペイナイトおよびパーライト，ペイナイ トに懸けて冷却した場合，焼もどし硬さ，軟化抵 抗が低下し，さらに実用硬さ HRC45 付近に調質 した時の靸延性および耐ヒートチェック性も劣化 することが判明した。これはべイナイトあるいは
ヘーライトナペイナイト変態域で析出した炭化物 が焼もどし時に凝集, 粗大化しゃすく，軟化抵抗 を劣化させるとともに脆性破壊の起点になるため と推察される。

さらに大型素材の均質性，方向性についても検 討した結果, 本実験で用いた $\phi 340$ の素材では, 鞄 延性に内外周の差は認められず，円周方向の值は 鍛造方向の70 85\%であることが判明した。

（文献）

1) K. Bungardt, O. Mulders, R. MeyerRhotert : Archiv. Eisenhüttenw. 37 (1966), 381

2）並木, 西尾，上原：鉄と鋼，64（1978）11, $\mathrm{S} 931$

3）上原，並木：鉄と鋼，65（1979）4，S 269

4) 伊藤, 常陸：電気製鋼，50（1979）3，181

5) D. P. Edwards: JISI, 207 (1969), 1494

6) Y. H. Liu : Trans. of ASM, 62 (1969), 55

7) D. H. Hung, G. Thomas : Met. Trans, 2 (1971), 1587

8) K. J. Irving, F. B. Pickering : JISI, 201 (1963), 518

9）鎌田, 腰塚, 船越：鉄之鋼，60（1974），372

10）鎌田，腰塚，船越：鉄と鋼，60 (1974)，1483

11）鎌田，腰塚，船越：鉄と鋼，61 (1975)，2839

12）荒木，辛，佐川：鉄と鋼，61 (1975)， 972

13）邦武，寺崎，大森：鉄と鋼，58（1972），1877

14）大谷，寺崎，邦武：鉄と鋼，58（1972），434

15) Y. Ohmori, H. Ohtani, T. Kunitake : Metal Science, 8 (1974), 357

16）富田, 宮本，岡林：鉄と鋼，64（1978），759

17）富田，中村，岡林：鉄と鋼，66（1980）, 523

18）岡林, 富田, 黒木：鉄と鋼, 62（1976）, 991

19) D. Webster : Trans. of ASM, 61 (1968), 816

20) G. Thomas: Met. Trans, 9 A (1978), 439

21）中島，荒木：鉄と鋼，61 (1975)， 3119

22) A. Randaku, A. Stanz, W. Webster: Stahl u. Eisem, 92 (1972), 981

23) L. Northcott, H. G. Baron: JISI, 184(1956) $12, \quad 385$

24) L. Kindbom: Arch. Eisenhuittenw., 35 (1964), 773

25) S. Malm, L. A. Nostrom : Metal Science, 13 
(1979), 544

26) K. S. Sabharwal, R. V. Wolf : 6th SDCE International die casting congress, (1970), Paper No. 71

27) K. Bungarot, H. Preisendanz, O. Mulders : Arichiv. Eisenhüttenw, 32 (1961), 561
28) K. Mehta : Tyssen Edelst. Tech. Ber., 4 (1978) 1,29

29) A. Kasak, G. Steven:6th SDCE International die casting congress, (1970), Paper No. 112

30）上原，並木：鉄と鋼，67（1981），S581

\title{
海外情 報
}

\section{疲労強度が重要となる構造用部品に使用される中炭素マイクロアロイング鋼}

\author{
by Claus Razim ; Metal Prog., 119 (1981) 6, 50 55
}

鋼の機械的性質を向上させるために焼入れ，焼 もどしすることは以前から行われているが，少量 の元素を添加して鋼の強度を上げることも可能で ある。ここではC，Nを調整し，Vを添加したマ イクロアロイング鋼 49MnVS3 (C 0.47, Si 0.34, Mn 0.77, P 0.023, S 0.053, Cr 0.13, V 0.12, N 0.0078）の自動車のクランクシャフトへの適用を 検討した。本マイクロフロイング鋼の疲労強度は, 熱処理を施さなくても焼入れ，焼もどしした

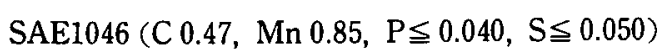
より大きい。また $550^{\circ} \mathrm{C} ， 600^{\circ} \mathrm{C} て ゙$ 焼もとし，その 後水焼入れすれは疲学强度はさらに改善される。 49MnVS3の組織はSAE1046 の焼ならし組織と 比べてとくに違いはない。乗用車のジーゼルェン ジンのクランクシャフトに限定して, 焼入れ, 焼 もどしを施したSAE1046 と比較した。49MnVS3
クランクシャフトの疲労強度の方がやや低かった が，実用的な見地からSAE1046の代替は可能で ある。

つぎに，さらに焼入性の良い37Cr4 (C 0.38, Si $0.28, \mathrm{Mn} 0.75, \mathrm{Cr} 1.05)$ と比較した。クランクシ 十フトとしての 49MnVS3 の引張強さはほほ同し であるが、靯性はかなり低く、調質鋼とマイクロ フロイング鋼の互換性の限界を示しているのかも しれない。マイクロフロイング鋼の利点をあげる と,クランクンャフト 1 個当りのコストがかなり 低くなる。切削加工中の変形抵抗が高いため, 切 削加工後の矯正加工が不要となる。

熱処理が省略でき，大きなエネルギーの節减と なる。被削性はS 約 $0.02 \%$ 添加することにより 向上する。唯一の欠点は比較的勒性が低いことで ある。(図 8，表 1) 